\title{
I am Somebody
}

\section{Angela Brown}

Abstract: I come this far by faith, leaning on the Lord, trusting in His Holy name. God has not failed me yet. Each time I fall, I come around, because, I come this far by faith.

\section{Valuing an Education}

A Child's day begins with

Finding a Solution

Finding a Solution

They want to learn

And be great things

But we fail to understand their cries

Because we failed our children

From pursuing their dreams

We as their parents have deprived our child

From funding their education

With the tools they deserved

Scarcity, the madness

Startling, the sadness

And the test scores are low

Our students are dropping out

With no room for hope

Our government is insecure

But students' passion to learn is high

They all want to earn the power

We must not hear their cries

In honesty we are not true to ourselves

In reality we aren't being fair to our children

We are ignoring the root of our problems

Starts from the person within

The whisper before dawn

The silence of visible light

Singing God's hymn infinitely in time.

Their words are a reflection of mourning

Not knowing foreshadowing history

We share their agony

We share their pain 
American Research Journal of English and Literature, Volume 1, Issue 5, 2015

ISSN 2378-9026

A mirror image of their journey.

Nothing is eternal

Only decades stand amongst our wound.

We stand, we bond, and we pledge words of hope

Every second, every minute,

Every hour in their memory

Each moment underlies our journey

And it is your voice that carries

Vicariously towards freedom.

A mind is a terrible thing to waste.

\section{Censorship}

Advocating Speech

Is life itself

Life is difficult without words

The presence of a voice

Carries on as a reminder

Of emerging thoughts

Thought remains unpinned

From aggression

I am the voice of

Advocating hope

From restriction

I am the voice of

Promoting peace

My voice demands justice

To be respected

My voice demands justice

To want dignity

I act in

Defiance to unkind difference

I act in

Response to unkempt change

My voice is a criminal of self-thought

Darkness is the impunity of silence

Speaking up is a right

I have something to say

Speaking out is a right 
American Research Journal of English and Literature, Volume 1, Issue 5, 2015

ISSN 2378-9026

I have something to say

My voice cannot be wasted

I have the right to be heard

Pro Choice

Having rights

I choose to life

My Choice

A right to do

As I choose

A right to choose

Choose who as I am

Choose who I am

Choose how I feel

With whom I will be

I have the right to will

To choose to be free

Free from denial

From will of hating

Killing without needs

Is not me

No one has the right

To tell me to create

I speaking freely, upon

Wanting, willing, needing

One, single, unison

To hold the right vocation

Freely feeling free

To bond with the one I love

To escape from being alone

To choose life, I am free

To choose life

To refute death

It's no right, not a right, not right

But a just right to choose life

My choice, to choose

To be a right, not to deny

Choices freely 
American Research Journal of English and Literature, Volume 1, Issue 5, 2015

ISSN 2378-9026

Because, just cause

To be removed does not

Follow the rules and

Gives me cause to act

I choose life

\section{Oral Tradition}

Gather my ten cents, my defenses, my senses

To defend the cause by the prayers of hope

Rescue me from the harsh winds of Katrina

Its breath did not care if you were black, white or Latino

Its breath did not care if you were rich or poor

For man to escape its evil path of death

Could not be avoided nor ignored.

But one of America's most remarkable cities

Will not be forgotten as a voice in the wind.

I pray on the idea, the violations to build won't be neglected

From the evil tactics, the schemes, and the rude attacks

Hope that the notions of morality will come into effect

And the unethical practices will not enact.

Fate will explore the city, as generations of legacies remembered

And the beauty, the cuisine, the music, will be restored

And Louisiana culture will fight back to survive

Its tradition will be remembered as part of American way of life

\section{NWA Movement}

It depends on how you see it

How you view it, how you perceive it

It is what you make of it

The reality of the truth in it

Is it the means of how it is partaken?

Or maybe it is how an identity is mistaken

In how it is viewed in the media

Profiled to profanity

Reasons of insanity

That dictates immortality for death

And the surreal images of sobriety

In reality people are dying

People are crying 
American Research Journal of English and Literature, Volume 1, Issue 5, 2015

ISSN 2378-9026

People are denying the truth

Of racial profiling is killing our race

People are protesting

Against police brutality

Of man slaughtering

Within decades in our communities

Some see it

Some don't believe in it

Some deny it as just cause

But to be perceived as a movement

Of immorality, a formality of reasons

To be recognized with negative sobriety

Of judgment that is deterrent of reasons

To be misunderstood for what some conceive

Labeled as ignorance in our streets

NWA of ignorance if you know the difference

It's no different than on the streets than now

Same protest, but it's all good

As we know it as incognizant to relevance

The life of a black man on the streets

Is procurement to industrialized slavery?

Words learned before our time

\section{It's Over}

Baby, what's up with us?

Things used to be different

You'd hold me in your arms

And tell me sweet nothings

Baby, what's up with this?

I kept my body tight

You would hug my hips

And rock me all night

Baby, tell me what's wrong

You used to Mac me down

And tell me I'm fine

That you could not live without me

You were the king of the castle

And I was your queen 
Whose boots are you knocked now

Your future sister?

What is it now, you played me

I'm not good enough

You can't rise above your ghetto queen

By being the man of my dreams

But I always thought we were better than that

This is a bridge, I dare not cross

Don't leave me hang in in the streets

Broken bottles, skeletons, reapers in the night

I'm afraid of what is underneath this bridge

We used to be real tight

Open the window and let the light shine through

I see you got that eye twinkle you had once

The same look when we made love

The dark heat caressing strokes

Our bodies compressed as one

I afraid of losing you

My only one true love

I've come to know

Does not choose to love me no more

I'm not for you

But what do you mean?

I cried many nights things were different

But it is what it seems

It is as it seems

You told me to walk

I left

It's over now

And I'm not over you

\section{Mom}

No matter if your down and blue

And you fear you will never make it

Dry your eyes, wipe your tears

Momma loves you

The times you fear you're all alone

And doubt you can make it on your own 
American Research Journal of English and Literature, Volume 1, Issue 5, 2015

ISSN 2378-9026

Believe that there is someone who really cares

Momma loves you

When they spit at you and call you names

And you fear that you're the one to blame

You must be comfortable within your own skin

And find the strength from within

Believe that you are special

Momma loves you

When you doubt that you're not good enough

And you feel weak and insecure

You're are not the blame for others ignorance

Hold your head up

Momma loves you

When voices tell you that you don't belong

You got that feeling you are treated wrong

Don't stop, fight for what is right

Place your faith in God follow the light

And always remember what Momma says

Be happy with who you are by being true to yourself

And never forget where in life you go

You are not alone, because,

Momma loves you

\section{Mourning a Child's Death}

To hold you in my arms

To feel your breath

To breathe every breath

With every beat of your heart

To know you are living

I am not worthy, I regret

Not knowing who you are

Not knowing who you've become

Not holding you close

Not letting you go

Not feeling your warmth

Not feeling your touch

I don't want you to hate me

With the stories told 
American Research Journal of English and Literature, Volume 1, Issue 5, 2015

ISSN 2378-9026

I'm with you always

Hope is a mystery

And it's not what it seems

Not what life is meant to be

Dreams fly away in the storm

When everything you had is gone

A light flickers in the night

Promises become un-kept secrets

That hunts you from the past

And everything is taken for granted

You stop loving yourself

You call out

And no one listens

No one dares to care

And you are all alone

Without a care in the world

Love is that matters most

Not until all is said and gone

You begin to learn

Behind every relationship

Losing a child is lost forever

Dad

My Dad is a one of a kind Dad

A man compassionate about life

As leader in the black community,

I followed his ideas and value his opinion.

Dad has a strong, positive guidance

His idea on life is to get an education.

My Dad always took the time to listen

Being careful that I make my own decisions.

Dad had a set of objectives that led the way

It is by choice, that I am more independent.

My Dad is the man, who has influenced me truly

To be a strong voice and a procurer of my dreams.

\section{A Used Book}

Forever and ever, their arrogance

Of repressed thoughts 
American Research Journal of English and Literature, Volume 1, Issue 5, 2015

ISSN 2378-9026

Disappearing in

And out of insanity

No one cares to understand

The poverty of words

A line, a phrase, or expression

Symbols turn unto stone

Stones turn unto ashes

Ashes turn unto dust

Words vanish and reappear

Amongst the wells of thought

Smoke signals self destruct for decades

While isolated from inclusion

Words die quietly of starvation

From the very wisdom

That controls our lives

And the knowledge

We need to unify our souls

From the familiar words

I used to know

\section{A Fallen Soldier}

I view the world

At attention.

I fight as

An exception

To the rule.

I find purpose

In defending

Our country.

Not knowing

The outcome

Of being judged.

I have a voice

in this war

It's my calling,

And I reply

Unmatched, unchanged.

My affiliation 
Is enlisted

To a nation

Of soldiers

Giving back

With respect

Unconditionally stated

In war and in peace

I stand tall

I fight brave

My voice heals

My is heard

I am soldier,

I am a retired veteran,

I am a U.S. scout

\section{Black lives matter}

And another ones gone

And another ones gone

Another one bites the dust

Do you know what it's like?

A victim of assault

Withholding silence

Enabled to talk

It is how it is

To be brought up in the streets

A gang is your family you trust

With your son's life

Not to repeat secrets

Is no way of life, ending lives

Your boy who wanted to live in your image

Dead under false pretences

Your little boys dream

Was to overcome obstacles with success

No not like this, not like this

To rise above this, 'tis be different

Different this time, next time, sometimes

'Cause we got options, to go and I walk

For the walking souls that die before us 
American Research Journal of English and Literature, Volume 1, Issue 5, 2015

ISSN 2378-9026

Cannot turn our backs, for once in time

To see eye to eye before one of our own dies

Because the price of life is more than its users

Another life is waited, without blame

I feel the pain I fear every time I leave the house

Hope next time this'll be different

And not another statistic

As God is our witness

\section{March on Selma, by Angela Khristin Brown}

It was the bloodiest day in history

The winter's cold was as hot as the summer's heat.

And the deadliest mark in American history was foretold

It is from fear that must have quenched God's thirst

That answered their call to freedom.

No hate or pain could deter their fate

For they walked for freedom.

They were descendants of bandage

And parterres for faith

Answering their ancestor's cry for mercy.

Racism pierced the dark corners of their mind,

'Will the right to have democracy be protected?'

And so they marched in the name of God's glory

To have their voices heard.

Virtue was the cause that could not wait

For discrimination is an extension of division.

It is a matter of time before chaos breaks

And the balances of interest become the voice of power.

Love is what surrenders in time

And forgiveness is with the heart of the people.

And so their march had cost many lives

But it is from their faith that redefined history.

\section{Eulogy of Race, by Angela Brown}

Every day is a eulogy on race

Every hour we face fear, as we pray and cope...

Another pale day we face, our race

Word have become a cold mystery of fate 
Words now hide behind its meaning

Dreams hide behind a cloud of mist

Brewed by the water boiling over

Every word lived is not promised

Every word tasted is savored

Words have become ideas

That emanated mixed feeling of bondage

Hidden words lie behind faux meaning

Words lost in meaning fading afar

Invisible to reason

My last words act freely

Time is darkness that feeds an addiction

To be loved and cared

Beyond my last request

Beyond this long journey

It is the hand that feeds my strength to carry on

It is the hand that has slain the star of death

Every day is a eulogy of race

Asking God to free our lost souls

With the wisdom to know better

With the heart to preach love

Every day is a eulogy on race

Every hour we face fear as we pray and cope another pale day

Words have become a cold mystery

Words lost hide behind meaning

Dreams hide behind a cloud of menagerie

That drifts and disappears in fear

Every word lived is not what it seems

Every word is borrowed time

Words are ideas alive

As you feel them finding

Hiding secrets behind the lies

Invisible to reason

My last words hold my fate

Having lost all meaning

Time is the dark that feeds

Behind your last request

That feeds the sane star of death 
American Research Journal of English and Literature, Volume 1, Issue 5, 2015

ISSN 2378-9026

\section{Retirement}

Think of how time passes

The winter splinters

The summer heat

The spring showers

The fall breeze

Many days, many months, many years have passed

From every concept, from every skill, and from every lesson taught

Through a students' gaze or a professor's eyebrow of surprise

Each moment we share has been a learning experience.

There are opportunities lost and found

Students graduate

A professor retires

And they leave to pursue their dreams.

As time passes there remains unfinished work

The friendships that bond

The conversations we share

For those times that we have shown we cared.

And for this bitter sweet memory

We must always reflect

On all these things

With an element of respect.

\section{Want You}

There is a man I call on

I'm drawn to answer my calls

A man, I'm drawn to his loving

Kisses, its man, my soul

Partner in life, is cool to have

Him talk to, laugh to, to

Answer my senses I'm drawn

To it's kind of man love lyrics.

This man has the crazy, cool, and loving

Flesh ripe skin tight finger lick in

Good, oh he's so fine He got me

Liken his intellectual skills words

Blowing my mind this cool cat got

Me he got me tongue twisted 
American Research Journal of English and Literature, Volume 1, Issue 5, 2015

ISSN 2378-9026

Hung over his lips I'm fallen deeper

Hung over drunken love so sweet

It's so sweet to have a man kind of

Twisted for my stuff Kind of want him

For me but to me it seems

He's afraid his hooked and we not

Sexed but temptation has it going

Down like that and if he asked

I'd go deeper into his mind

And do him again I could not do

It alone not with myself but with

A guy like that caught in the habit

I got to have it in for him and him

Had done me the same we eventually

I want him around more often to

Create our peace, make our peace

Make the heat sustain got to have it

Got to want it got to love it the same

Me you he and its faint nothing I can do bad

All by me 'cause I'm a woman with needs

In need of a man - This aim's no stuff this time

I'm for real...I want you

\section{A Child's View on War}

Daddy went off to war one day

To play the big boy games

And fight the countless enemies

Who also have no names?

While I sat and played outside

And mommy baked her pies

I said to my little playmates

'My daddy will not die.

He'll fight the ones who want to take

Our freedoms and our dreams

He's goanna blast those commies,

Though I don't know what that means.'

But Daddy's strong, he'll survive,

My Mommy told me so. 
So I was brave and did not cry

When he said he had to go.

My mother told me once again,

That Daddy would not die,

So I gave him a smile to carry

When we had to say goodbye.

I was right, but oh, so wrong,

To think he would not die

Because although he still walks and talks

There's nothing in his eyes.

When Daddy came back, he looked the same

And hugged and kissed my head

But soon I knew his heart was gone

His love for me was dead.

This Vietnam that he went to

Was oh, so far away

And while he did his duty there

I learned how to pray.

"Lord, please bring my daddy home,

And keep him safe at night,

And if it's dark and cold outside

Give him warmth and light.”

What I should have prayed instead was this:

“Lord, protect my Daddy's heart,

And don't let the war he's fighting

Tear his soul apart."

Yes, Daddy went off to war one day

Mommy said he would not die

But that was not completely true,

'Cause now he's dead inside. 